\title{
STUDI SOSIO-LEGAL TERHADAP KETERTIBAN DAN KETENTRAMAN DI KABUPATEN SIDOARJO
}

\author{
Victor Imanuel W. Nalle \\ *Dosen Fakultas Hukum Universitas Katolik Darma Cendika, Surabaya \\ Korespondensi:victor.imanuel@ukdc.ac.id,vicnalle@yahoo.com \\ Naskah dikirim: 31 Mei 2016 \\ Naskah diterima untuk diterbitkan: 5 Agustus 2016
}

\begin{abstract}
Peace and order is a city needs. Achievement of these needs by local governments through regulatory instruments, namely the Regional Regulation. Sidoarjo regency set through Peraturan Daerah No. 10 of 2013. This study through socio-legal approach has been assessing the condition of the aspects that affect the implementation of the local regulation and constraints. This study shows that there are gaps in the understanding of the urgency of the substance of Peraturan Daerah No. 10 of 2013 for the public interest. In addition, conditions of law enforcement structures and culture of the people do not support the implementation of the Peraturan Daerah No. 10 of 2013. These conditions resulted in the emergence of obstacles to achieve peace and order indistrict of Sidoarjo.
\end{abstract}

Keywords: effectiveness of law, public order, legal awareness

\begin{abstract}
Abstrak
Ketentraman dan ketertiban merupakan sebuah kebutuhan kota. Pencapaian kebutuhan tersebut dilakukan oleh pemerintah daerah melalui instrumen pengaturan yaitu Peraturan Daerah. Kabupaten Sidoarjo mengaturnya melalui Peraturan Daerah Nomor 10 Tahun 2013. Penelitian ini melalui pendekatan sosio-legal telah mengkaji kondisi aspek-aspek yang mempengaruhi implementasi peraturan daerah tersebut maupun hambatan-hambatannya. Penelitian ini menunjukkan bahwa terdapat kesenjangan dalam pemahaman warga terhadap urgensi substansi Peraturan Daerah Nomor 10 Tahun 2013 bagi kepentingan publik. Selain itu kondisi struktur penegak hukum dan kultur masyarakat tidak mendukung implementasi Peraturan Daerah Nomor 10 Tahun 2013. Kondisi ini mengakibatkan munculnya hambatan-hambatan untuk mencapai ketentraman dan ketertiban di Kabupatan Sidoarjo.
\end{abstract}

Kata kunci: efektivitas hukum, ketertiban umum, kesadaran hukum

Tersedia versi daring: http://jhp.ui.ac.id DOI: http://dx.doi.org/10.21143/jhp.vol47.no3.94 


\section{Pendahuluan}

Kota pada hakikatnya adalah suatu tempat yang akan berkembang terus menerus sesuai dengan perkembangan zaman dan potensi yang dimilikinya. Dalam perkembangannya, segala aspek akan ikut tumbuh dan berkembang serta memunculkan permasalahan yang kompleks pula. Perkembangan dan perubahan suatu kota terjadi pada kondisi fisik, ekonomi, sosial dan politik. Pemerintah sebagai pembuat kebijakan seharusnya mempertahankan atau memelihara sesuatu yang baik tentang kota dan berupaya merencanakan pertumbuhan dan perubahannya.

Sebagai wujud dari pengaturan terhadap daerah, setiap Pemerintah Kabupaten/Kota di seluruh Indonesia berupaya melakukan pengaturan terhadap kegiatan-kegiatan yang dinilai mengganggu aktivitas masyarakat atau ketertiban umum. Bentuk konkrit pengaturan tersebut adalah dengan membentuk peraturan daerah dalam rangka mengatasi masalah ketertiban umum.

Berdasarkan Pasal 12 ayat (1) Undang-Undang Nomor 23 Tahun 2014 tentang Pemerintahan Daerah (UU No. 23 Tahun 2014), ketentraman dan ketertiban umum merupakan kewenangan Pemerintah Daerah sebagai Urusan Pemerintahan Wajib yang berkaitan dengan pelayanan dasar. Kewenangan Pemerintah Kabupaten/Kota dalam ketentraman dan ketertiban umum antara lain meliputi:

1. penanganan gangguan ketentraman dan ketertiban umum dalam 1 (satu) Daerah kabupaten/kota;

2. penegakan Perda Kabupaten/Kota dan peraturan bupati/walikota;

3. pembinaan PPNS kabupaten/kota.

Dalam rangka melaksanakan kewenangan Pemerintah Daerah tersebut, diperlukan instrumen hukum yang mengatur aspek ketentraman dan ketertiban umum beserta ancaman sanksinya. Pemerintah Daerah pada umumnya membentuk Perda tentang Ketentraman dan Ketertiban Umum. Tidak terkecuali Pemerintah Kabupaten Sidoarjo yang telah membentuk Peraturan Daerah Nomor 10 Tahun 2013 tentang Ketertiban Umum dan Ketentraman Masyarakat (Perda No. 10 Tahun 2013).

Berdasarkan Perda No. 10 Tahun 2013, terdapat 8 (delapan) ruang lingkup ketertiban umum dan ketentraman umum di Kabupaten Sidoarjo. Delapan ruang lingkup tersebut antara lain:

1. tertib jalan, jalur hijau, trotoar, taman dan fasilitas umum lainnya;

2. tertib sungai, saluran, kolam;

3. tertib lingkungan;

4. tertib tempat dan usaha tertentu;

5. tertib bangunan;

6. tertib sosial;

7. tertib kesehatan; dan

8. tertib tempat hiburan dan keramaian. 
Tercapainya kedelapan ketentraman dan ketertiban tersebut hanya dapat terjadi jika Perda No. 10 Tahun 2013 dalam penegakannya berjalan efektif. Namun penegakan sebuah peraturan perundang-undangan pada umumnya menemui hambatan. Selalu ada kesenjangan (gap) antara hukum dalam teks dan hukum dalam kenyataan di masyarakat. Kesenjangan tersebut dapat terjadi karena berbagai aspek.

Aspek-aspek yang mempengaruhi kesenjangan antara hukum dalam teks dan hukum kenyataan antara lain:

1. aspek kebijakan, yaitu bagaimana kebijakan yang dibuat oleh Pemerintah Kabupaten Sidoarjo dapat mendorong kepatuhan warga, optimalisasi pengawasan implementasi Perda, dan lainlain.

2. Aspek kelembagaan, yaitu bagaimana kondisi kelembagaan yang berperan dalam mensosialisasikan dan mengedukasi Perda terkait kepada masyarakat, maupun yang menegakkannya.

3. Aspek infrastruktur, yaitu bagaimana Pemerintah Kabupaten Sidoarjo menyediakan infrastruktur yang dapat mendorong kepatuhan warga terhadap Perda terkait sekaligus menekan biaya kepatuhan yang harus dikeluarkan warga agar dapat mematuhi Perda.

Terkait konteks implementasi Perda No. 10 Tahun 2013, perlu diketahui sejauhmana efektivitas penegakan Perda No. 10 Tahun 2013 di masyarakat. Penegakan Perda No. 10 Tahun 2013 harus dievaluasi agar dapat diidentifikasi hambatan dan kelemahan dalam penegakan Perda tersebut. Dengan demikian dapat diidentifikasi perubahan yang perlu dilakukan terkait penegakan Perda No. 10 Tahun 2013 agar tujuan ketentraman dan ketertiban di Kabupaten Sidoarjo dapat tercapai.

\section{Rumusan Masalah}

Melihat adanya kesenjangan antara kenyataan yang terjadi dengan yang seharusnya diharapkan, maka perlu dilakukan penelitian untuk mengetahui sejauh mana efektivitas penerapan Perda No. 10 Tahun 2013 tersebut. Oleh karena itu, berdasarkan latar belakang tersebut, penulis telah melakukan penelitian dengan rumusan masalah sebagai berikut:

1. Bagaimana aspek penunjang penyelenggaraan penegakan Perda Bidang Ketentraman dan Ketertiban di Kabupaten Sidoarjo?

2. Apa hambatan atau kendala dalam penyelenggaraan penegakan Perda Bidang Ketentraman dan Ketertiban di Kabupaten Sidoarjo?

\section{Metode Penelitian}

Penelitian ini merupakan penelitian sosio-legal. Penelitian sosiolegal dikenal juga sebagai penelitian nondoktrinal. Penelitian nondoktrinal menempatkan hasil amatan atas realitas-realitas sosial untuk 
tidak ditempatkan sebagai proposisi umum. Penelitian nondoktrinal mencari pola-pola keajegan atau pola-pola hubungan (korelasi atau kausal) antara berbagai gejala yang memanifestasikan hadirnya hukum di alam kenyataan. ${ }^{1}$

Penelitian ini menggunakan pendekatan deskriptif analitis, yaitu prosedur atau pemecahan masalah penelitian dilakukan dengan cara memaparkan obyek yang diselidiki sebagaimana adanya berdasarkan fakta-fakta aktual pada saat sekarang tidak terbatashanya sampai pada pengumpulan data tetapi meliputi analisis dan interpretasi tentang arti data-data tersebut. Selain itu, penelitian sosio-legal juga menggunakan beberapa pendekatan yang digunakan untuk menganalisis bahan hukum primer dan bahan hukum sekunder. Pendekatan tersebut antara lain pendekatan peraturan perundang-undangan dan pendekatan konseptual.

Untuk memperoleh data dan informasi yang sesuai dengan permasalahan yang dikemukakan sebelumnya, maka dilakukan penelitian di Kabupaten Sidoarjo. Penelitian pada instansi-instansi yang terkait di Kabupaten Sidoarjo meliputi Satpol PP Kabupaten Sidoarjo, Dinas Perhubungan Kabupaten Sidoarjo, Dinas Kebersihan dan Pertamanan Kabupaten Sidoarjo, Dinas Sosial Kabupaten Sidoarjo, Kantor Kecamatan Taman, Kantor Kecamatan Sidoarjo, Kantor Kecamatan Gedangan, dan Kantor Kecamatan Buduran.

Data dalam penelitian adalah data primer dan data sekunder. Data primer merupakan data yang diperoleh secara langsung dari lapangan. Data sekunder dalam penelitian ini adalah buku, jurnal, dan dokumendokumen yang terkait dengan penelitian ini dan diperoleh melalui studi kepustakaan. Selain itu juga digunakan bahan hukum primer, yaitu peraturan perundang-undangan yang berkaitan dengan penelitian ini.

Pengumpulan data diawali dengan pengumpulan data sekunder melalui studi kepustakaan. Data sekunder yang telah dianalisis akan digunakan sebagai pedoman untuk membuat daftar pertanyaan. Daftar pertanyaan tersebut digunakan nantinya sebagai instrument untuk pengumpulan data primer melalui wawancara mendalam (indepth interview) kepada informan dan responden. Data dari responden dilakukan dengan menggunakan metode accidental sampling. Berdasarkan metode tersebut, maka responden yang dipilih adalah responden yang ditemukan sedang melakukan pelanggaran Perda No. 10 Tahun 2013 di wilayah Kabupaten Sidoarjo.

Proses analisis data dilakukan secara terus menerus dimulai dengan menelaah seluruh data yang tersedia dari berbagai sumber. Analisis data dilakukan secara kualitatif terhadap informasi-informasi yang diperoleh dari wawancara maupun studi kepustakaan. Analisis data dilakukan setelah tahap pengumpulan data. Kajian terhadap pelaksanaan Perda No. 10 Tahun 2013 bukan hanya dari sisi normatifnya namun juga berkaitan

1 Soetandyo Wignjosoebroto, Hukum: Konsep dan Metode, (Malang: Setara Press, 2013), hlm. 120. 
dengan berbagai fenomena yang terjadi selama pelaksanaan perda tersebut.

\section{Hasil Penelitian dan Pembahasan}

\section{Ruang Lingkup Pelanggaran Ketertiban Umum dan Ketentraman Masyarakat dalam Perda No. 10 Tahun 2013}

Istilah ketertiban umum menurut Kollewijn memiliki sejumlah variasi pengertian. Pertama, ketertiban umum dalam hukum perikatan merupakan batasan dari asas kebebasan berkontrak. Kedua, sebagai unsur pokok dalam "ketertiban dan kesejahteraan, keamanan" (rust en veiligheid). Ketiga, sebagai pasangan dari "kesusilaan yang baik" (goede zeden). Keempat, sebagai sinonim dari "ketertiban hukum" (rechtsorde), ataupun - kelima - "keadilan." Keenam, sebagai pengertian dalam hukum acara pidana untuk jalannya peradilan yang adil, dan terakhir kewajiban hakim untuk mempergunakan pasal-pasal dari perundangundangan tertentu. ${ }^{2}$

Menurut Yu Un Oppusunggu, ketertiban umum berbeda dengan kepentingan umum. Secara konseptual, kepentingan umum berarti menjaga kepentingan masyarakat luas atau kepentingan bersama, yang sekaligus diperhadapkan (vis-à-vis) dengan kepentingan kelompok, golongan atau individu. Kepentingan umum menjadi, misalnya, dasar untuk menggusur atau mengambil sebagian atau seluruh tanah milik seseorang untuk tujuan pembangunan sarana dan prasarana publik. Untuk keperluan tersebut Pemerintah dapat menetapkan jumlah ganti kerugian sepihak, sesuai dengan kemampuan keuangannya. Oleh karena penggusuran tersebut adalah untuk kepentingan umum, maka pihak yang tergusur dapat menerima uang ganti kerugian yang sepihak tadi. Dalam penerapan kepentingan umum terdapat kebutuhan praktis dari masyarakat. Namun kepentingan umum bukanlah suatu dasar atau alasan pengesamping bagi keberlakuan hukum asing. Sebaliknya, ketertiban umum tidak dapat dijadikan dasar untuk penggusuran. Penerapan ketertiban umum adalah suatu kebutuhan normatif dan ideal. ${ }^{3}$

Acuan yuridis normatif dalam mendefinisikan ketertiban umum dan ketentraman masyarakat adalah Peraturan Pemerintah Nomor 6 Tahun 2010 tentang Satuan Polisi Pamong Praja (PP No. 6 Tahun 2010). Berdasarkan Pasal 1 Angka 10 PP No. 6 Tahun 2010, ketertiban umum dan ketentraman masyarakat adalah suatu keadaan dinamis yang memungkinkan Pemerintah, pemerintah daerah, dan masyarakat dapat melakukan kegiatannya dengan tenteram, tertib, dan teratur. Definisi

2 Yu Un Oppusunggu, Pertemuan Ilmu Hukum dan Sosiologi dalam Penerapan Lembaga Ketertiban Umum, "Law, Society \& Development”, Vol. II, No. 3, (Agustus November, 2008).

${ }^{3}$ Ibid. 
dalam ketentuan PP No. 6 Tahun 2010 menunjukkan bahwa kondisi ketertiban umum dan ketentraman masyarakat tidak lahir dari kondisi masyarakat dalam pemerintahan otoriter. Kondisi ketertiban umum dan ketentraman tersebut terjadi dalam kondisi yang dinamis. Artinya, masyarakat secara aktif menjalankan kehidupan bermasyarakat tanpa tekanan. Selain masyarakat, Pemerintah dan pemerintah daerah juga dapat melaksanakan kerja pemerintahan dengan baik.

Berdasarkan Perda tersebut diatur 8 (delapan) jenis ketertiban umum dan ketentraman masyarakat. Delapan jenis ketertiban umum dan ketentraman masyarakat tersebut antara lain:

a. tertib jalan, jalur hijau, trotoar, taman dan fasilitas umum lainnya (Pasal 3, 4, dan 5);

b. tertib sungai, saluran, kolam (Pasal 6 dan 7);

c. tertib lingkungan (Pasal 8);

d. tertib tempat dan usaha tertentu (Pasal 9);

e. tertib bangunan (Pasal 11);

f. tertib sosial (Pasal 12 dan 13);

g. tertib kesehatan (Pasal 14, 15, 16, 17, dan 18); dan

h. tertib tempat hiburan dan keramaian (Pasal 19, 20, dan 21).

2. Gambaran Penegakan Perda No. 10 Tahun 2013 (Maret 2015Oktober 2015)

Data penegakan Perda No. 10 Tahun 2013 menunjukkan bahwa selama periode Maret 2015 sampai dengan Oktober 2015 telah terjadi 438 (empat ratus tiga puluh delapan) pelanggaran Perda No. 10 Tahun 2013. Data tersebut menunjukkan bahwa persebaran penegakan Perda No. 10 Tahun 2013 selama periode tersebut hanya terfokus pada kecamatan-kecamatan tertentu saja. Tabel 1 menunjukkan persebaran wilayah pelanggaran tersebut.

Tabel 1. Persebaran Wilayah Pelanggaran Perda No. 10 Tahun 2013 (Maret 2015-Oktober 2015)

\begin{tabular}{|c|l|c|c|}
\hline No & \multicolumn{1}{|c|}{ Kecamatan } & $\begin{array}{c}\text { Jumlah } \\
\text { Pelanggaran }\end{array}$ & $\%$ \\
\hline 1 & Kecamatan Sidoarjo & 291 & $66,44 \%$ \\
\hline 2 & Kecamatan Waru & 56 & $12,79 \%$ \\
\hline 3 & Kecamatan Gedangan & 52 & $11,87 \%$ \\
\hline 4 & Kecamatan Candi & 20 & $4,57 \%$ \\
\hline 5 & Kecamatan Buduran & 18 & $4,11 \%$ \\
\hline 6 & Kecamatan Krian & 1 & $0,23 \%$ \\
\hline & Total & 438 & $100,00 \%$ \\
\hline
\end{tabular}

Sumber: Satpol PP Kabupaten Sidoarjo 
Berdasarkan data persebaran wilayah pelanggaran dalam Tabel 4.5 dapat dikemukakan beberapa kemungkinan tentang pelanggaran yang terjadi di Kabupaten Sidoarjo. Beberapa kemungkinan tersebut antara lain:

a. Intensifikasi penegakan Perda No. 10 Tahun 2013 hanya terfokus pada Kecamatan Sidoarjo, Kecamatan Waru, dan Kecamatan Gedangan. Intensifikasi penegakan Perda yang hanya terfokus pada ketiga kecamatan tersebut akan memunculkan bias terhadap persebaran pelanggaran Perda No. 10 Tahun 2013. Bias tersebut akan menyebabkan adanya persepsi bahwa pelanggaran Perda No. 10 Tahun 2013 paling tinggi terdapat di ketiga kecamatan tersebut. Walaupun tidak tertutup kemungkinan bahwa pelanggaran pada kecamatankecamatan lainnya juga terjadi pada intensitas yang tinggi. Namun jika penegakan Perda tidak mencakup seluruh kecamatan dengan intensitas yang sama maka akan menimbulkan bias terhadap data persebaran pelanggaran.

b. Pelanggaran terbanyak di Kecamatan Sidoarjo dapat disebabkan karena Kecamatan Sidoarjo merupakan ibukota Kabupaten Sidoarjo. Kecamatan Waru dan Kecamatan Gedangan sebagai kecamatan terdekat dengan Kecamatan Sidoarjo juga turut terpengaruh oleh faktor tersebut. Perkembangan suatu wilayah perkotaan, industri, masyarakat dan berbagai masalah sosial yang mengikutinya merupakan faktor penentu terwujudnya kriminalitas atau kejahatan di perkotaan (epidemiologi kriminal) sehingga sebuah kota dengan sendirinya juga merupakan produsen dari kejahatan yang terwujud di perkotaan (criminogenic). Pada umumnya terdapat korelasi yang sangat signifikan antara ketidakmampuan daya dukung lingkungan kota, industrialisasi yang lebih berorientasi kepentingan ekonomi dan urbanisasi yang tidak terkendali telah menimbulkan berbagai permasalahan sosial bagi warga kota itu sendiri (epidemiologi kriminalitas) yang bermuara kepada terbentuknya berbagai kejahatan di perkotaan (urban crime) dan juga pelanggaran-pelanggaran hukum dalam bentuk yang lebih ringan. ${ }^{4}$

Émile Durkheim berpendapat bahwa perubahan yang terjadi sebagai hasil dari transisi masyarakat agraris di pedesaan menuju masyarakat industri di perkotaan turut berpengaruh pada pelanggaranpelanggaran hukum yang terjadi di perkotaan. Menurut Durkheim, perubahan sosial yang cepat (rapid social change) dan pertumbuhan akan menjadikan kota sebagai tempat yang potensial terbentuknya kejahatan di

\footnotetext{
${ }^{4}$ Rycko Amelza Dahniel, Pengelolaan Mobilitas Penduduk guna Mencegah Konflik Sosial dalam Kangka Ketahanan Nasional, 〈http://polisikita.id/index.php/kriminologi/44-pengelolaan-mobilitas-penduduk>, diakses tanggal 10 Desember 2015.
} 
perkotaan. Walaupun perubahan yang lambat dari sebuah kota ataupun stabil, wilayah perkotaan akan tetap menjadi criminogenic. Gelombang urbanisasi dan ekologi dari kota merupakan penyumbang dari terbentuknya criminogenic. ${ }^{5}$

Pengaruh atau dampak gelombang urbanisasi sebagaimana dijelaskan Durkheim maupun teori ketidakteraturan sosial tersebut dapat dilihat pada arus pendatang yang masuk ke Kecamatan Sidoarjo sebagai ibukota Kabupaten Sidoarjo. Berdasarkan data Sidoarjo Dalam Angka 2015, arus pendatang yang masuk tersebut jauh lebih tinggi daripada kecamatan-kecamatan lainnya yang berada di wilayah pinggiran Kabupaten Sidoarjo, misalnya Kecamatan Jabon. Pendatang yang masuk ke Kecamatan Sidoarjo selama tahun 2014 mencapai 3.958 jiwa, sedangkan pendatang yang masuk ke Kecamatan Sidoarjo pada tahun yang sama hanya mencapai 801 jiwa.

Pengaruh jumlah pendatang di Kabupaten Sidoarjo terhadap pelanggaran Perda No. 10 Tahun 2013 juga dapat dilihat pada asal wilayah pelanggar Perda. Berdasarkan data pelanggaran Perda No. 10 Tahun 2013 yang telah diproses, jumlah pelanggar terbanyak kedua adalah penduduk dari luar Kabupaten Sidoarjo, yaitu sebanyak 140 (seratus empat puluh) pelanggar.

Tabel 2. Wilayah Asal Pelanggar Perda No. 10 Tahun 2013 (Maret 2015-Oktober 2015)

\begin{tabular}{|r|l|r|r|}
\hline No & Asal Wilayah Pe langgar & Jumlah & \% \\
\hline 1 & Kecamatan Sidoarjo & 155 & $35.39 \%$ \\
\hline 2 & Luar Sidoarjo & 140 & $31.96 \%$ \\
\hline 3 & Kecamatan Candi & 49 & $11.19 \%$ \\
\hline 4 & Kecamatan Gedangan & 31 & $7.08 \%$ \\
\hline 5 & Kecamatan Waru & 29 & $6.62 \%$ \\
\hline 6 & Kecamatan Buduran & 14 & $3.20 \%$ \\
\hline 7 & Kecamatan Wonoayu & 5 & $1.14 \%$ \\
\hline 8 & Kecamatan Porong & 4 & $0.91 \%$ \\
\hline 9 & Kecamatan Tanggulangin & 3 & $0.68 \%$ \\
\hline 10 & Kecamatan Tulangan & 3 & $0.68 \%$ \\
\hline 11 & Kecamatan Taman & 2 & $0.46 \%$ \\
\hline 12 & Kecamatan Balongbendo & 1 & $0.23 \%$ \\
\hline 13 & Kecamatan Prambon & 1 & $0.23 \%$ \\
\hline 14 & Kecamatan Krian & 1 & $0.23 \%$ \\
\hline \multicolumn{2}{|c|}{ Total } & $\mathbf{4 3 8}$ & $\mathbf{1 0 0 . 0 0 \%}$ \\
\hline
\end{tabular}

Sumber: Satpol PP Kabupaten Sidoarjo

5 Robert D. Crutchfield dan Charis E. Kubrin, Urban Crime - Are Crime Rates Higher In Urban Areas?, Explaining Urban Crime, Explaining Variation In Urban Crime, <http://law.jrank.org/pages/2227/Urban-Crime.html>, diakses tanggal 10 Desember 2015 . 
Data pada Tabel 2 tidak serta merta menunjukkan bahwa pelanggar Perda No. 10 Tahun 2013 terbanyak adalah penduduk Kecamatan Sidoarjo. Hal ini disebabkan kecenderungan intensifikasi penegakan Perda pada Kecamatan Sidoarjo dan tidak merata pada kecamatankecamatan selain sekitar Kecamatan Sidoarjo. Oleh karena itu data tersebut harus dianalisis dengan melihat keterkaitannya pada data persebaran wilayah pelanggaran Perda.

Data pada Tabel 2 jika dikaitkan dengan persebaran wilayah pelanggaran menunjukkan bahwa pelanggar Perda No. 10 Tahun 2013 cenderung berasal dari wilayah terdekat yang menjadi lokasi terbanyak pelanggaran, yaitu Kecamatan Sidoarjo. Pelanggar terbanyak berasal dari Kecamatan Sidoarjo, Kecamatan Candi, Kecamatan Waru, dan Kecamatan Buduran.

Selain wilayah pelanggaran dan pelanggar, data penegakan Perda No. 10 Tahun 2013 selama periode Maret 2015-Oktober 2015 juga menunjukkan terbatasnya ruang lingkup pelanggaran yang ditindak oleh Pemerintah Kabupaten Sidoarjo. Sebagian besar dari 438 pelanggaran yang ditindak oleh Pemerintah Kabupaten Sidoarjo adalah pelanggaran terhadap tertib jalan, jalur hijau, trotoar, taman dan fasilitas umum lainnya. Penegakan Perda No. 10 Tahun 2013 terhadap tertib jalan, jalur hijau, trotoar, taman dan fasilitas umum lainnya mayoritas mencakup pelanggaran berupa penggunaan jalan, trotoar, jalur hijau, dan taman selain untuk peruntukannya. Sebagian besar pelanggar melakukan pelanggaran terhadap ketentuan tersebut karena menggunakan jalan, trotoar, jalur hijau, dan taman untuk berjualan.

Jika dikaitkan dengan analisis sebelumnya, yaitu wilayah pelanggaran, sebagian besar pelanggaran terhadap tertib jalan, trotoar, jalur hijau, dan taman, dan fasilitas umum lainnya dilakukan di Kecamatan Sidoarjo. Data tersebut menunjukkan bahwa pertumbuhan ekonomi dan pembangunan yang pesat di ibukota Kabupaten mendorong tumbuhnya sektor-sektor informal dalam pemenuhan kebutuhan hidup sehari-hari. Data pelanggaran selama periode Maret 2015-Oktober 2015 juga menunjukkan bahwa pelanggaran juga dilakukan oleh nonpenduduk Kabupaten Sidoarjo atau pendatang, misalnya pendatang dari Bangkalan, Gresik, Jember, dan lain-lain.

Oleh karena itu secara terpisah perlu dianalisis apakah Pemerintah Kabupaten Sidoarjo telah mengantisipasi tumbuhnya sektor-sektor informal yang mencari nafkah di wilayah yang pertumbuhan ekonominya pesat. Tumbuhnya sektor-sektor informal tersebut berpotensi untuk menyebabkan terjadinya pelanggaran hukum dalam upaya mendapatkan akses-akses peningkatan sumber pendapatan oleh masyarakat.

Penegakan terhadap tertib lingkungan (Pasal 8 Perda No. 10 Tahun 2013) juga serupa dengan penegakan terhadap tertib jalan, trotoar, jalur hijau, dan taman, dan fasilitas umum lainnya. Penegakan terhadap tertib 
lingkungan dalam Pasal 8 lebih banyak terfokus pada penertiban pada pedagang kaki lima sebagai sektor informal di masyarakat. Penegakan terhadap ketentuan tertib lingkungan lebih banyak terfokus pada pelanggaran berupa mendirikan kios dan berjualan atau perbuatan yang dapat mengakibatkan kerusakan dan berubahnya fungsi taman dan jalur hijau atau menjajakan barang dagangan di jalur hijau, taman dan tempat umum.

Data pelanggaran tersebut juga menunjukkan bahwa terdapat kemungkinan bias dalam mengidentifikasi pelanggaran Perda. Bias pada data pelanggaran disebabkan intensifikasi penegakan Perda hanya difokuskan pada penertiban pedagang kaki lima. Jika intensifikasi penegakan Perda hanya pada pedagang kaki lima, maka tidak tertutup kemungkinan adanya jumlah pelanggaran yang juga besar pada jenisjenis pelanggaran ketertiban umum dan ketentraman masyarakat lainnya. Data selengkapnya mengenai jenis pelanggaran Perda yang diproses selama Maret 2015-Oktober 2015 dapat dilihat pada Gambar 1.

\section{Gambar 1. Jenis Pelanggaran yang diproses (Maret 2015-Oktober 2015)}

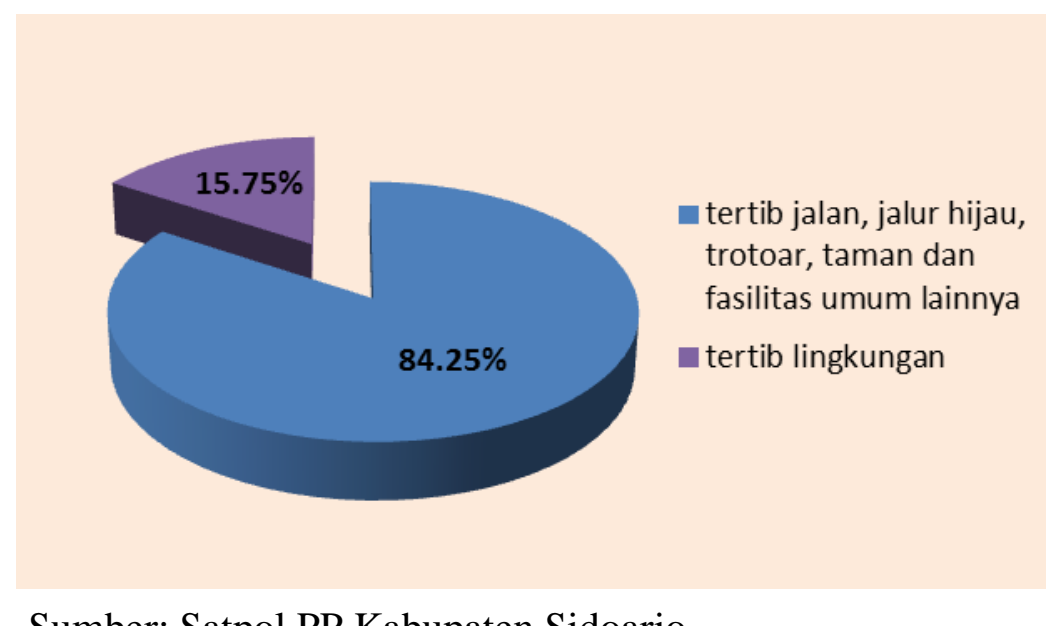

Sumber: Satpol PP Kabupaten Sidoarjo

\section{Aspek Penunjang Penyelenggaraan Perda No. 10 Tahun 2013}

Hukum dapat efektif di masyarakat, selain karena dipahami dan diyakini baik, juga seharusnya menjadi manifestasi sosio kultural masyarakat. Agar dapat menjadi manifestasi sosio kultural, maka seharusnya aturan hukum yang dibuat merupakan manifestasi dari spirit sosio kultural untuk melakukan perubahan di masyarakat. Jika aturan hukum tersebut muncul secara semena-mena dan bukan manifestasi spirit sosio kultural, maka akan terkendala pada penerimaan masyarakat kepada aturan hukum tersebut, dan bukan sekedar pada pemahaman substansi aturan hukum. 
Menurut Lawrence Friedman, untuk kepentingan analisis teoretik, demi kedayagunaannya yang praktikal, hukum nasional sebagai suatu sistem institusional, harus dikenali dalam tiga aspeknya. Ketiga aspek tersebut ialah substansi perundang-undangan, struktur organisasi dalam penegakannya, dan yang ketiga ialah kultur yang akan ikut menjadi determinan bermakna-tidaknya hukum dalam kehidupan masyarakat dari hari ke hari. Merupakan suatu kekeliruan apabila upaya mengefektifkan bekerjanya hukum (penegakan hukum) hanya berkonsentrasi pada kerja memperbaiki atau mengamandemen hukum perundang-undangannya saja tanpa membenahi struktur organisasi yang ada pada sistem hukum nasional. Demikian juga akan menjadi permasalahan jika dalam kerja penegakan hukum hanya berkonsentrasi pada intensi kekuatan struktural dan mengabaikan interpretasi kultural para insan pencari keadilan. ${ }^{6}$

Upaya penegakan hukum tidak lagi harus dibataskan hanya pada kerja-kerja polisionil yang di dalam bahasa Inggris disebut 'legal enforcement' melainkan kerja mereformasi sistem hukum. Kerja reformasi hukum inipun sudah semestinya tak cuma dibataskan pada memperbaharui hukum undang-undang semata - yang di dalam bahasa Inggris disebut legal reform, melainkan law reform. Adapun yang tercakup dalam pengertian law reform ini, yang juga akan mencakup apa yang disebut judicial reform, ialah seluruh proses yang dijalani untuk menelaah seluruh aspek sistem perundang-undangan yang ada, dalam rangka upaya mengefektifkan perubahan di dalam sistem hukum yang ada demi tertingkatkannya efisiensi sistem dalam fungsinya memberikan layanan kepada khalayak ramai yang tengah mencari keadilan. ${ }^{7}$

Berdasarkan teori Friedman tersebut, akan dianalisis aspek penunjang penyelenggaraan Perda No. 10 Tahun 2013. Analisis ini akan melihat bagaimana substansi Perda No. 10 Tahun 2013 dipahami oleh masyarakat. Pemahaman masyarakat tersebut penting untuk diidentifikasi karena ada beberapa kemungkinan yang dapat dimunculkan. Selain itu analisis ini akan melihat bagaimana struktur lembaga penegak hukum yang berperan dalam menegakkan pelaksanaan Perda No. 10 Tahun 2013.

\section{a. Substansi Perda No. 10 Tahun 2013}

Pengetahuan penduduk Kabupaten Sidoarjo terhadap adanya Perda No. 10 Tahun 2013 masih rendah. Berdasarkan survei secara accidental sampling, terhadap 32 (tiga puluh dua) responden yang melakukan pelanggaran Perda No. 10 Tahun 2013, ditemukan bahwa 24 (dua puluh empat) di antaranya tidak mengetahui adanya Perda No. 10 Tahun 2013 yang mengatur ketertiban umum dan ketentraman masyarakat di Kabupaten Sidoarjo. Hanya 8 (delapan) responden yang mengetahui

${ }^{6}$ Dinal Fedrianet.al, Dialektika Pembaruan Hukum Indonesia, (Jakarta: Sekretariat Jenderal Komisi Yudisial RI, 2012), hlm. 4.

${ }^{7}$ Ibid. 
adanya Perda No. 10 Tahun 2013. Namun dari 8 responden tersebut, tidak ada yang mengetahui bahwa tindakan yang dilakukannya merupakan pelanggaran terhadap Perda No. 10 Tahun 2013.

\section{Gambar 2. Pengetahuan Responden terhadap Perda No. 10 Tahun 2013}

Apakah Anda mengetahui adanya Perda No. 10 Tahun 2013 yang mengatur ketertiban umum dan ketentraman masyarakat di Kabupaten Sidoarjo?

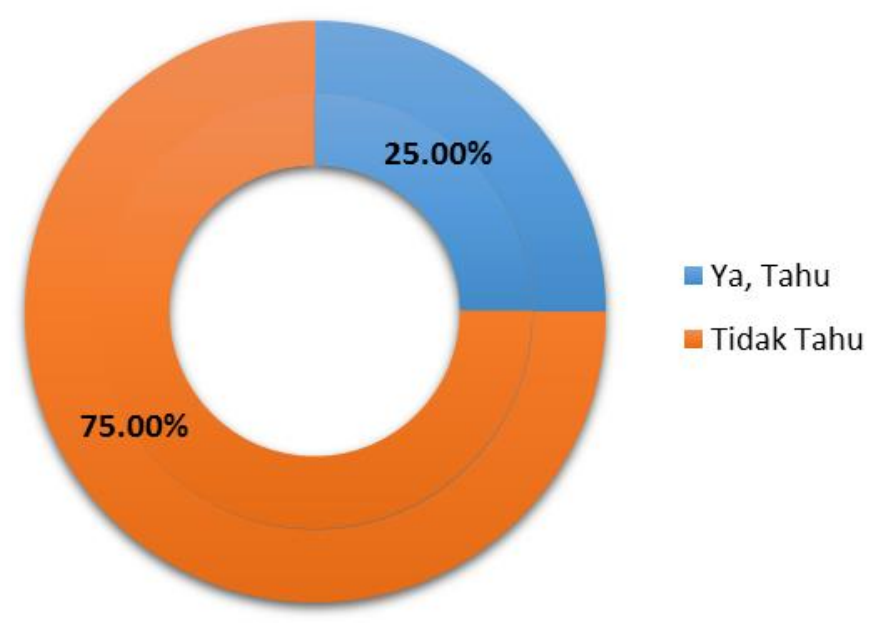

Sumber: data primer

Namun tidak berarti bahwa responden yang tidak mengetahui adanya Perda No. 10 Tahun 2013 adalah responden yang belum pernah mengalami penegakan Perda No. 10 Tahun 2013. Salah satu respoden yang merupakan pedagang, misalnya, sebelumnya pernah digusur oleh Satpol PP karena berdagang di tempat umum tanpa izin. Namun responden yang bersangkutan ternyata tidak pernah mendapatkan sosialisasi atau penjelasan dari pihak Satpol PP mengenai ketentuan apa yang dilanggar sehingga harus menerima upaya penggusuran dari pemerintah. ${ }^{8}$

Tiga puluh satu responden dari 32 responden pelanggar Perda No. 10 Tahun 2013 saat diwawancarai menyatakan tidak pernah mendengar adanya sosialisasi Perda No. 10 Tahun 2013. Kondisi ini menunjukkan minimnya pengetahuan warga terhadap adanya Perda No. 10 Tahun 2013. Kondisi ini juga menunjukkan bahwa sosialisasi Perda No. 10 Tahun 2013 masih belum menjangkau seluruh penduduk Kabupaten Sidoarjo. Padahal Perda No. 10 Tahun 2013 tersebut pernah dilanggar sebelumnya. Selain cakupan wilayah sosialisasi, intensifikasi sosialisasi 2015.

${ }^{8}$ Wawancara dengan Guruh, penduduk Kabupaten Sidoarjo, tanggal 29 Oktober 
memegang peranan penting. Intensifikasi tersebut seharusnya dapat dilakukan dalam berbagai bentuk.

Selain itu terdapat 7 (tujuh) responden pelanggar Perda No. 10 Tahun 2013 yang menyatakan bahwa substansi Perda No. 10 Tahun 2013 bersifat diskriminatif dan merugikannya. Dua responden menyatakan bahwa substansi Perda tersebut merugikan warga yang mencari nafkah dengan berjualan, sementara akses warga untuk memiliki tempat berjualan tidak mudah, karena terbentur harga sewa dan biaya lainnya. Responden lainnya menyatakan bahwa ketentuan tersebut diskriminatif karena hanya sesuai jika diterapkan di daerah perkotaan seperti Kecamatan Sidoarjo. Namun jika diterapkan di daerah pedesaan akan merugikan. Misalnya dalam ketentuan larangan membiarkan hewan berkeliaran. Bagi responden lainnya, tertib bangunan juga dianggap memberatkan pemilik bangunan pribadi.

\section{Gambar 3. Pemahaman terhadap Ketentuan Diskriminatif}

Apakah menurut Anda substansi Perda No. 10 Tahun 2013 merugikan dan diskriminatif?

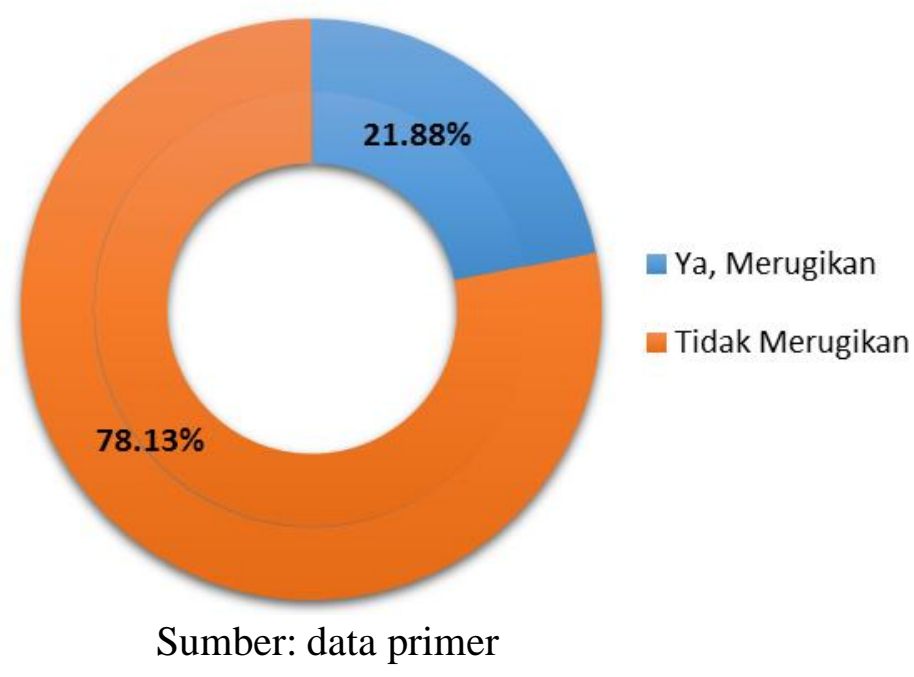

Masih adanya pemahaman masyarakat bahwa ketentuan Perda tersebut merugikan disebabkan belum adanya kesadaran Perda tersebut memberikan manfaat bagi masyarakat. Menurut Soerjono Soekanto, berprosesnya tahap memahami hukum menjadi menghargai hukum adalah bila dalam proses memahami tersebut warga masyarakat menghayati tentang adanya manfaat hukum bagi kehidupan bersama di dalam masyarakat bersangkutan, dan hal ini bila warga masyarakat tersebut mengetahui tujuan dan tugas hukum yang sesungguhnya diperlukan bagi kepentingan umum..$^{9}$ Oleh karena kesadaran hukum

\footnotetext{
${ }^{9}$ Soerjono Soekanto, Beberapa Cara dan Mekanisme dalam Penyuluhan Hukum, (Jakarta: Pradnya Paramita, 1986), hlm. 5.
} 
harus dicapai terlebih dahulu agar masyarakat dapat memiliki pemahaman yang baik terhadap Perda tersebut.

Kesadaran hukum masyarakat adalah merupakan keluaran (output) dari proses kegiatan penyuluhan yang mencapai tingkat optimalisasi ideal yang ditandai dengan timbulnya rasa untuk menghargai hukum. Jika mengacu pada Peraturan Menteri Hukum dan Hak Asasi Manusia RI Nomor M.01-PR.08.10 Tahun 2006 Tentang Pola Penyuluhan Hukum, kesadaran hukum masyarakat adalah nilai yang hidup dalam masyarakat adalah bentuk pemahaman dan ketaatan atau kepatuhan masyarakat terhadap norma hukum dan peraturan perundang-undangan yang berlaku.

Rendahnya kesadaran dan pemahaman masyarakat terhadap Perda No. 10 Tahun 2013 dapat disebabkan materi muatan Perda tersebut merupakan lapangan hukum netral. Pengetahuan dan pemahaman hukum masyarakat jauh lebih baik untuk lapangan-lapangan hukum yang nonnetral jika dibandingkan dengan lapangan hukum netral. Lapangan hukum non-netral adalah lapangan hukum yang dekat dengan suasana kehidupan agama dan kepercayaan atau dekat dengan kebudayaan, sedangkan lapangan hukum netral adalah lapangan hukum yang tidak berkaitan erat dengan agama, kepercayaan atau kebudayaan. Ini berarti pula pemahaman masyarakat dengan kaedah (kaedah sosial yang kemudian diangkat menjadi kaedah hukum) hukum yang tumbuh dari bawah jauh lebih baik jika dibandingkan dengan kaedah hukum yang dituangkan dari atas. Jika pemahaman dan pengetahuan masyarakat tentang kaedah hukum itu termasuk tentang isi kaedah hukum itu sudah baik maka kemungkinan masyarakat untuk mematuhi atau mentaatinya lebih terbuka.

Perda No. 10 Tahun 2013 mengatur masalah ketertiban umum dan ketentraman masyarakat tetapi dengan materi muatan yang bagi beberapa warga tidak dekat dengan suasana agama maupun kebudayaan. Misalnya, masalah berjualan di tempat umum tanpa izin. Bagi beberapa warga, trotoar dan ruang publik merupakan ruang bersama bagi masyarakat dalam menjalankan kegiatan. Oleh karena itu terdapat perbedaan dalam memaknai materi muatan Perda No. 10 Tahun 2013.

Selain itu, kesadaran hukum masyarakat adalah perihal ilmu hukum keperilakuan (behavioral jurisprudence) individu, maka termasuk wahana psikologis hukum. Terdapat kemungkinan apa yang dikehendaki hukum itu tidak sejalan dengan kesadaran hukum masyarakat karena hukum tersebut dibentuk tanpa memperhatikan aspek psikologis warga masyarakat. Menurut Satjipto Rahardjo, dalam mewujudkan hukum sebagai sebenar-benarnya ilmu harus mendialogkan the state of the arts dalam sains, dengan paradigma adalah "hukum untuk manusia", dan bukan sebaliknya. ${ }^{10}$

10 Satjipto Rahardjo, Hukum dalam Jagat Ketertiban, (Jakarta: Penerbit UKI Press, 2006), hlm. 55. 
Dengan demikian, jelas bahwa kesadaran hukum adalah lebih tepat bila dilihat sebagai wahana psikologi hukum. Kesadaran hukum pada hakikatnya adalah "kesetiaan" seseorang atau subjek hukum terhadap hukum itu yang kemudian diwujudkan dalam bentuk prilaku nyata. Secara psikologis kesadaran hukum masih bersifat abstrak, dan baru bersifat konkret atau senyatanya setelah diwujudkan dalam perilaku nyata. Karenanya kesadaran hukum yang menjadi tujuan penyuluhan hukum adalah kesadaran hukum yang diwujudkan dalam bentuk prilaku nyata. Letak kesadaran hukum berada dalam dunia abstrak, sebagai pilihan olah pemikiran untuk menghargai hukum dan sekaligus berada dalam dunia nyata atau dunia perilakunya yang diwujudkan dalam kepatuhan terhadap hukum.

Oleh karena itu, cara atau teknik penyuluhan yang komunikatif dan mampu menyentuh hati nurani warga masyarakat untuk menghargai hukum, yang dapat efektif untuk menimbulkan kesadaran hukum masyarakat. Apabila sudah menemukan teknik penyuluhan yang tepat guna maka masalah kontinuitas dan masalah luasnya jangkauan wilayah penyuluhan juga merupakan hal penting untuk suksesnya penyuluhan hukum, dan ujung-ujungnya secara manajerial suksesnya kegiatan penyuluhan hukum akan bermuara pada tersedianya fasilitas dan biaya penyelenggaraan.

Untuk sampai pada tingkat kesadaran hukum masyarakat, maka segi manfaat atau kegunaan hukum haruslah betul-betul dapat dipahami oleh setiap warga masyarakat. Sebaliknya, informasi dalam penyuluhan hukum cenderung memperkenalkan hukum pada masyarakat sebagai sesuatu yang menakutkan, sesuatu yang merepotkan, dan sesuatu yang hanya ideal dalam norma tapi tidak konsisten dalam pelaksanaannya. Kondisi ini harus dinetralisir sehingga masyarakat menjadi berpersepsi yang baik atau menguntungkan tentang hukum. ${ }^{11}$ Penghargaan atau penilaian positif terhadap hukum untuk pembentukannya sangat dipengaruhi oleh fakta hukum yang membentuk opini dan persepsi masyarakat tentang hukum. Media massa yang memunculkan berita dan tayangan visual tentang berbagai peristiwa yang secara kategoristik memperkeruh opini dan persepsi masyarakat terhadap hukum, disadari atau tidak merupakan suatu hal yang merugikan kegiatan penyuluhan hukum dalam rangka menumbuhkan kesadaran hukum masyarakat.

\section{b. Struktur Hukum dalam Penegakan Perda No. 10 Tahun 2013}

Berdasarkan data yang diperoleh dari informan SKPD, permasalahan dalam struktur hukum untuk penegakan Perda No. 10 Tahun 2013 terkait dengan keterbatasan sumber daya manusia. Keterbatasan terutama di tingkat kecamatan karena kurangnya personil

${ }^{11}$ Tim Penelitian BPHN, Penelitian Hukum tentang Dampak Penyuluhan Hukum terhadap Tingkat Kesadaran Hukum Masyarakat, (Jakarta: BPHN, 2011), hlm. 12. 
Polisi Pamong Praja di tingkat kecamatan dalam melakukan penegakan hukum Perda tersebut. ${ }^{12}$

Kesulitan Satpol PP Kabupaten Sidoarjo sebagai SKPD yang memiliki tupoksi penegakan Perda No. 10 Tahun 2013 adalah dalam hal koordinasi dengan SKPD lain. Ruang lingkup Perda No. 10 Tahun 2013 terlampau luas dan berkaitan dengan tupoksi SKPD lainnya. SKPD lain yang berhubungan dengan Perda No. 10 Tahun 2013 ini misalnya Dinas Kebersihan dan Pertamanan, Dinas Kebersihan dan Pertamanan, serta Dinas Sosial. Namun ruang lingkup yang terlampau luas tersebut tidak dapat dijangkau seluruhnya oleh Satpol PP. Satpol PP hanya dapat melakukan penindakan terhadap pelanggaran tertib jalan, jalur hijau, trotoar, taman dan fasilitas umum lainnya serta tertib lingkungan. ${ }^{13}$

Efektivitas penegakan Perda No. 10 Tahun 2013 di tingkat kecamatan juga masih minim. Minimnya jumlah personil di tingkat kecamatan yang bertugas melakukan penegakan Perda No. 10 Tahun 2013 berpengaruh terhadap efektivitas penegakannya. Selain keterbatasan jumlah personil, secara kualitatif terdapat keterbatasan Penyidik Pegawai Negeri Sipil (PPNS) di tingkat kecamatan. Padahal adanya PPNS dapat berpengaruh secara signifikan pada penegakan Perda karena PPNS berwenang untuk melakukan penyidikan terhadap pelanggaran Perda No. 10 Tahun 2013. Kelemahan lainnya di tingkat kecamatan terkait dengan kurangnya koordinasi antara Polisi Pamong Praja di tingkat kecamatan dengan Satpol PP di tingkat kabupaten. ${ }^{14}$

Selain itu, struktur yang dapat menjadi ujung tombak dalam implementasi Perda No. 10 Tahun 2013 tetapi kurang dilibatkan adalah pemerintah desa. Pemerintah di tingkatan desa dapat berperan dalam mensosialisasikan Perda dan juga melakukan tindakan-tindakan preventif dalam mencegah pelanggaran Perda. Saat ini langkah yang dilakukan di tingkatan desa telah dilakukan oleh aparat di tingkat kecamatan dengan melakukan patrol rutin di desa. ${ }^{15}$

Kondisi yang terjadi dalam implementasi Perda No. 10 Tahun 2013 oleh struktur hukum tersebut menggambarkan perlunya:

1) perubahan substansi Perda agar ruang lingkup pelanggaran tidak terlampau luas tetapi dapat dijalankan dan penegakan hukumnya dapat berjalan efektif oleh struktur hukum di Kabupaten Sidoarjo.

2) Peningkatan koordinasi antara Satpol PP Kabupaten Sidoarjo dengan SKPD lain yang terkait dengan implementasi Perda No. 10 Tahun 2013.

12 Wawancara dengan M. Sulton Hasan, Kasi Penyidikan dan Penyelidikan Satpol PP Kabupaten Sidoarjo, tanggal 26 Oktober 2015.

${ }^{13} \mathrm{Ibid}$.

14 Wawancara dengan Subambang, Kasi Trantib Kecamatan Waru, tanggal 26 Oktober 2015.

${ }^{15}$ Wawancara dengan Arief Agus, Kasi Trantib Kecamatan Gedangan, tanggal 27 Oktober 2015. 
3) Peningkatan kuantitas dan kualitas sumber daya manusia (aparat) yang berperan sebagai penegak implementasi Perda No. 10 Tahun 2013. Sumber daya manusia yang seharusnya disiapkan dalam melaksanakan perda tersebut adalah yang berjiwa sebagai pengayom masyarakat yang memenuhi standarisasi latihan dasar sebagai polisi pamong praja dan mempunyai kualitas komunikasi, dedikasi mental yang teruji serta kemampuan dalam menguasai substansi perundangundangan. ${ }^{16}$

\section{c. Budaya Hukum dalam Implementasi Perda No. 10 Tahun 2013}

Dalam konteks budaya, pengertian budaya hukum dimaksud dapat diperhalus menjadi seperangkat nilai, gagasan, norma yang menjadi pedoman berpikir, berucap, berperilaku, bertindak sesuai dengan yang diharapkan oleh sebagian besar warga masyarakat setempat. Budaya hukum masyarakat merupakan seperangkat nilai, gagasan, norma yang terbangun oleh budi dan daya warga masyarakat setempat dan telah terinternalisasi ke dalam alam kesadaran (mindset) secara turun temurun dan berfungsi sebagai pedoman yang menghubungkan antara aturan hukum pada tataran ide di satu pihak dan perilaku atau tindakan nyata pada tataran praksis di lain pihak yang diharapkan warga masyarakat. ${ }^{17}$

Pemahaman tersebut berakar ke dalam nilai-nilai normatif bersama yang terlahir dan terbangun dalam masyarakat serta terinternalisasi ke dalam kehidupan masyarakat. Artinya, kelahiran suatu budaya hukum berasal dari proses internal selama perkembangan masyarakat berlangsung, dan selama itu pula interaksi baik antarwarga maupun antara warga dengan warga dari luar berlangsung membentuk perilaku yang semakin mempola. Akhirnya pola tindakan dimaksud dianggap sebagai yang benar dan dijadikan pedoman bertindak oleh sebagian besar warga masyarakat. ${ }^{18}$

Nilai yang dianut warga terhadap peraturan perundang-undangan, khususnya Perda No. 10 Tahun 2013, dapat dilihat pada alasan-alasan yang dikemukakan pelanggar Perda No. 10 Tahun 2013. Berdasarkan wawancara yang dilakukan terhadap 32 (tiga puluh dua) respon yang diperoleh dengan accidental sampling, terdapat 9 (sembilan) responden yang menyatakan bahwa larangan-larangan dalam Perda No. 10 Tahun 2013 membebani kehidupannya.

\section{Gambar 4. Perda No. 10 Tahun 2013 sebagai Beban Masyarakat}

Apakah substansi Perda No. 10 Tahun 2013 membebani Anda?

\footnotetext{
16 Wawancara dengan Widiyantoro Basuki, Kabid Kebersihan, Dinas Kebersihan dan Pertamanan Kabupaten Sidoarjo, tanggal 26 Oktober 2015.

${ }^{17}$ Dinal Fedrian, et.al, op. cit, hlm. 188.

${ }^{18}$ Ibid.
} 


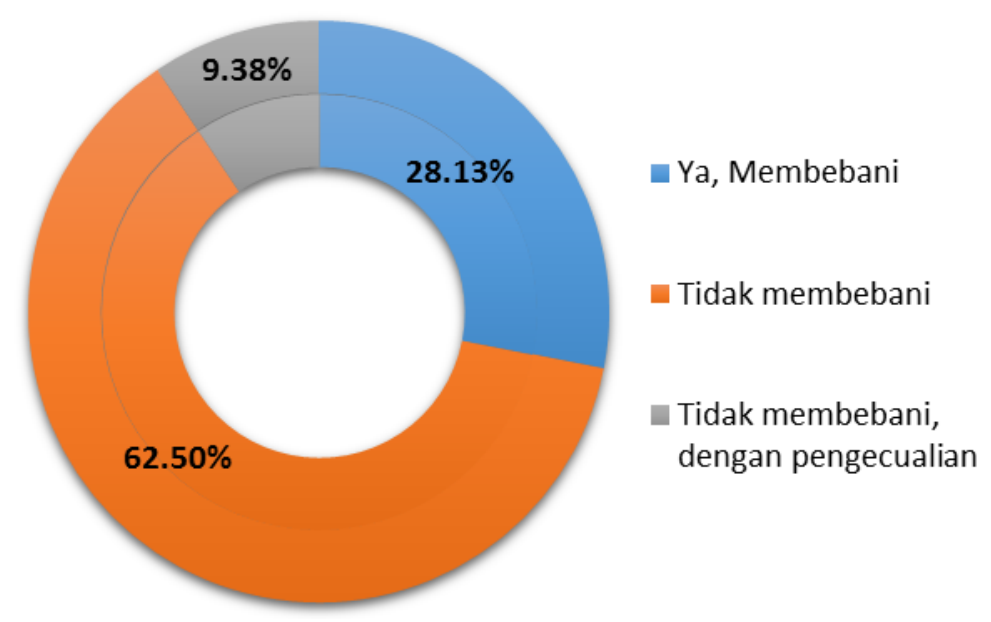

Sumber: data primer

Pandangan bahwa Perda tersebut membebani disebabkan beberapa pandangan berikut:

1) Kultur jalan pintas dalam mencapai tujuan-tujuan yang diinginkan. Sebagian warga merasa dibebani jika harus menempuh prosedur atau langkah yang lama untuk melakukan sesuatu. Misalnya, dalam hal berjualan di fasilitas umum. Fasilitas umum tidak dilihat sebagai milik bersama yang tidak boleh diokupasi untuk kepentingan ekonomi pribadi. Namun data pelanggaran terbanyak yang ditindak oleh Satpol PP menunjukkan bahwa pelanggaran didominasi pedagang kaki lima. Pedagang kaki lima tersebut memanfaatkan fasilitas publik karena menganggap bahwa membuka usaha atau berjualan dengan langkah-langkah prosedural justru terhambat. ${ }^{19}$

2) Tidak adanya sarana yang menunjang ketaatan terhadap Perda. Sebagai contoh adalah alasan atau keluhan beberapa warga bahwa sulitnya menemukan tempat sampah mendorong mereka untuk membuang sampah sembarangan di tempat-tempat umum. Warga yang berpendapat demikian memiliki pandangan bahwa Perda No. 10 Tahun 2013 pada hakikatnya tidak membebani, dengan catatan bahwa Pemerintah Daerah menyiapkan sarana yang menunjang. Sebagai contoh, terkait dengan sanitasi dan larangan untuk mandi dan buang air sembarangan di sungai. Menurut warga, jika larangan tersebut diimbangi dengan pembangunan sarana, mungkin tidak memberatkan. Jika ada warga yang tidak punya kamar mandi dan kamar mandi umum 2015.

${ }_{19}$ Wawancara dengan Guruh, penduduk Kabupaten Sidoarjo, tanggal 29 Oktober 
terbatas, maka akan cenderung mengambil jalan pintas dengan mandi dan buang air di sungai. ${ }^{20}$

3) Perda No. 10 Tahun 2013 dianggap membebani karena materi muatan dalam Perda tersebut melarang perilaku yang menjadi keseharian masyarakat. Sebagai contoh adalah larangan untuk membiarkan hewan peliharaan berkeliaran di jalan. Bagi masyarakat pedesaan, perilaku tersebut merupakan keseharian dan dianggap sebagai kewajaran. Namun perilaku tersebut ternyata menjadi larangan dalam Perda No. 10 Tahun 2013 yang tentunya ditujukan untuk ketertiban maupun keamanan pengguna jalan. Oleh karena itu bagi masyarakat justru menjadi beban karena bertolakbelakang dengan kenyataan perilaku sehari-hari yang dianggap wajar.

Jika melihat pandangan atau nilai yang dianut masyarakat sebagai responden, maka terlihat bahwa ada kesenjangan antara beberapa substansi Perda No. 10 Tahun 2013. Beberapa konsep larangan dalam Perda No. 10 Tahun 2013 terlihat asing dan tidak sesuai dengan pandangan yang wajar bagi masyarakat. Misalnya, larangan untuk parkir di atas trotoar tentunya akan sulit dipahami bagi beberapa orang ${ }^{21}$ karena konsep trotoar sebagai wilayah pedestrian belum menjadi pemikiran mayoritas masyarakat di Kabupaten Sidoarjo yang bercampur antara masyarakat perkotaan dan agraris.

Dalam konteks ini, Perda No. 10 Tahun 2013 menjadi hukum yang ditransplantasikan dalam kehidupan bermasyarakat. Transplantasi hukum dengan demikian mencakup pada proses untuk memindahkan aturan, doktrin, institusi hukum dari satu masyarakat ke masyarakat lain, dari satu negara ke negara lain atau satu rumpun sistem hukum ke dalam sistem hukum lain yang bisa jadi menganut paham yang berbeda-beda. Transplantasi hukum, sampai pada tataran perumusan norma hukum dalam suatu peraturan perundang-undangan (positivisasi), pada umumnya, tidak menimbulkan permasalahan yang signifikan. Namun permasalahan akan muncul justru pada tataran implementasi hukum. Hal ini dapat dimengerti oleh karena hukum, pada galibnya tidak hanya rumusan kalimat yang "mati", tetapi lebih merupakan kristalisasi nilainilai yang berkembang dan dikembangkan pada lingkungan masyarakat di mana hukum itu tumbuh.

Transplantasi hukum, memungkinkan terjadinya benturan atau potensi benturan antara hukum "asing" dengan hukum lokal. Dalam setiap pemberlakuan hukum pastilah terkandung harapan-harapan (ekspektasi) tertentu baik dari pembentuk hukum maupun dari kelompok masyarakat yang menjadi obyek pengaturannya. Mungkin juga terjadi

20 Wawancara dengan Mukhdor Faruq, penduduk Kabupaten Sidoarjo, tanggal 29 Oktober 2015.

${ }^{21}$ Wawancara dengan Rangga Yudo Wicaksono, penduduk Kabupaten Sidoarjo, tanggal 29 Oktober 2015. 
koreksi dari kelompok-kelompok lain yang memiliki kepentingan baik secara langsung maupun tidak langsung terhadap permasalahan tersebut. Dalam kenyataannya, apa yang diharapkan tidak selalu sesuai dengan apa yang terjadi pada ranah praksis.

\section{Hambatan atau Kendala Penyelenggaraan Penegakan Perda No. 10 Tahun 2013}

a. Keterbatasan sumber daya manusia dalam penegakan hukum

Keterbatasan sumber daya manusia mencakup dua aspek, yaitu aspek kualitas dan kuantitas. Aspek kualitas mencakup pemahaman seluruh penyelenggara pemerintahan di Kabupaten Sidoarjo, hingga tingkat desa, terhadap Perda No. 10 Tahun 2013. Penegakan Perda No. 10 Tahun 2013 selama ini banyak bergantung pada Satpol PP di tingkat Kabupaten Sidoarjo maupun tingkat kecamatan. Padahal kuantitas personil maupun anggaran mempengaruhi ruang gerak Satpol PP dalam melakukan pengawasan kepatuhan masyarakat terhadap Perda No. 10 Tahun 2013. Keterbatasan tersebut tidak diimbangi dengan aparat pemerintahan di tingkatan paling rendah.

Data yang ada menunjukkan bahwa terdapat keterbatasan Satpol PP dalam menjalankan penegakan hukum hingga seluruh kecamatan di Kabupaten Sidoarjo. Penegakan hukum selama Maret-Oktober 2015 menunjukkan cakupannya hanya terbatas pada 6 (enam) kecamatan dari 18 (delapan belas) kecamatan di Kabupaten Sidoarjo. Keterbatasan penegakan hukum tersebut disebabkan keterbatasan kuantitas Satpol PP di tingkat maupun Polisi Pamong Praja di tingkat kecamatan.

Oleh karena itu keterbatasan tersebut harus diimbangi dengan kualitas penyelenggara pemerintahan di tingkat desa dalam upaya-upaya meningkatkan pemahaman masyarakat terhadap Perda No. 10 Tahun 2013. Keberhasilan Perda No. 10 Tahun 2013 tentunya bukan diukur dari makin meingkatnya pelanggaran yang ditangani oleh PPNS. Indikator keberhasilan Perda No. 10 Tahun 2013 adalah ketika masyarakat tidak lagi melakukan pelanggaran-pelanggaran yang dilarang oleh Perda No. 10 Tahun 2013.

Domain pemerintah desa dalam penyelenggaraan ketentraman dan ketertiban telah diatur dalam Undang-Undang Nomor 6 Tahun 2014 tentang Desa (UU No. 6 Tahun 2014). Berdasarkan Pasal 26 ayat (2) huruf g UU No. 6 Tahun 2014, Kepala Desa berwenang membina ketentraman dan ketertiban masyarakat Desa. Selain itu dalam Pasal 80 ayat (4) huruf e diatur bahwa prioritas, program, kegiatan, dan kebutuhan Pembangunan Desa dirumuskan berdasarkan penilaian terhadap kebutuhan masyarakat Desa yang salah satunya meliputi peningkatan kualitas ketertiban dan ketentraman masyarakat Desa berdasarkan kebutuhan masyarakat Desa. 
b. Sanksi pidana belum tentu memberikan efek jera

Penegakan hukum dalam penyelenggaraan Perda No. 10 Tahun 2013 selama ini dilihat tidak mampu memberikan efek jera bagi masyarakat. ${ }^{22}$ Padahal sanksi telah diberikan bagi para pelanggar dan pelanggaran tersebut terpublikasikan lewat media. Namun masih ada masyarakat yang tidak merasa terancam oleh adanya sanksi pidana sehingga masih melakukan pelanggaran. ${ }^{23}$

Berkenaan dengan penggunaan sanksi pidana sebagai sarana penanggulangan kejahatan, kajian hukum pidana pada umumnya membedakan bentuk sanksi menjadi dua, yaitu pidana (straf) dan tindakan (maatregel). Menurut Sholehuddin keduanya bersumber dari ide dasar yang berbeda. Sanksi pidana bersumber pada ide dasar: "mengapa diadakan pemidanaan". Sanksi tindakan bertolak dari ide dasar: "untuk apa diadakan pemidanaan itu". Bertolak dari ide dasar yang berbeda membawa konsekuensi sifat kedua sanksi itu berbeda pula. Sanksi pidana bersifat reaktif terhadap suatu perbuatan, sedangkan sanksi tindakan lebih bersifat antisipatif terhadap pelaku perbuatan tersebut. Fokus sanksi pidana ditujukan pada perbuatan salah yang dilakukan seseorang melalui pengenaan penderitaan agar yang bersangkutan menjadi jera, sedangkan sanksi tindakan lebih terarah pada upaya memberi pertolongan pada pelaku agar ia berubah. ${ }^{24}$

Sanksi pidana lebih menekankan unsur pembalasan (pengimbalan) yang merupakan penderitaan yang sengaja dibebankan kepada seorang pelanggar, sedangkan sanksi tindakan, bersumber dari ide dasar perlindungan masyarakat dan pembinaan atau perawatan si pembuat. J.E. Jonkers menyatakan titik berat sanksi pidana adalah pada pidana yang diterapkan untuk kejahatan yang dilakukan, sedangkan sanksi tindakan mempunyai tujuan yang bersifat sosial. ${ }^{25}$

Dilihat dari segi tujuan, sanksi pidana maupun sanksi tindakan juga bertolak dari ide dasar yang berbeda. Sanksi pidana bertujuan memberi penderitaan kepada pelanggar supaya pelanggar merasakan akibat dari perbuatannya, serta berpikir bahwa perbuatan yang telah dilakukan memperoleh pencelaan dari masyarakat. Dengan demikian, perbedaan prinsip dengan sanksi tindakan terletak pada ada tidaknya unsur pencelaan, bukan pada ada tidaknya unsur penderitaan, sedangkan pada sanksi tindakan tujuannya lebih bersifat mendidik.

Secara teoretik, dalam sanksi tindakan tidak ada unsur pembalasan, karena tindakan itu ditujukan pada prevensi khusus, yakni melindungi

22 Wawancara dengan Wiyono, Kabid Sosial Dinas Sosial Kabupaten Sidoarjo, tanggal 29 Oktober 2015.

${ }^{23} \mathrm{Ibid}$.

${ }^{24}$ Sholehuddin, Sistem Sanksi dalam Hukum Pidana: lde Dasar Double Track Sistem \& Implementasinya, (Jakarta: PT Raja Grafindo Persada, 2003), hlm. 17.

25 J.E. Jonkers, Buku Pedoman Hukum Pidana Hindia Belanda, (Jakarta: PT. Bina Aksara, 1987), hlm. 350. 
masyarakat dari ancaman yang dapat merugikan kepentingan masyarakat itu Singkatnya, sanksi pidana berorientasi pada ide pengenaan sanksi terhadap pelaku suatu perbuatan, sementara sanksi tindakan berorientasi pada ide perlindungan masyarakat. Dengan demikian sanksi pidana dan tindakan memiliki perbedaan ide dasar, tujuan, dan sifatnya. Kedua jenis sanksi tersebut ditetapkan dalam kedudukan yang sejajar atau setara dalam kebijakan legislasi.

Kajian yang ada selama ini tidak menunjukkan bahwa salah satu dari sanksi pidana atau sanksi tindakan lebih baik dan efektif. Kedua jenis sanksi tersebut dapat digunakan secara bersama-sama. Tujuan dari pengenaan sanksi harus diarahkan bukan semata-mata untuk memberikan efek jera. Tujuan dari pengenaan sanksi harus diarahkan untuk memberikan perlindungan kepada kepentingan masyarakat secara luas.

Jika dikaitkan dengan kepentingan masyarakat secara luas, khususnya dalam ketertiban dan ketentraman, maka tujuan sanksi dalam Perda No. 10 Tahun 2013 tidak diposisikan sebagai pemberi efek jera saja. Sanksi dalam Perda No. 10 Tahun 2013 ditujukan untuk mengembalikan kondisi ketertiban dan ketentraman dalam masyarakat. Pelanggar Perda yang merusak tatanan ketertiban dan ketentraman mungkin saja telah jera, tetapi tatanan ketertiban dan ketentraman yang telah diubahnya tentu harus diperbaiki. Jika tatanan tersebut tidak diperbaiki maka besar kemungkinan terjadi pengulangan pelanggaranpelanggaran Perda No. 10 Tahun 2013 oleh anggota masyarakat lainnya.

Selain itu dalam Peraturan Menteri Dalam Negeri Nomor 54 Tahun 2011 tentang Standar Operasional Prosedur Satuan Polisi Pamong Praja (Permendagri No. 54 Tahun 2011) juga menunjukkan bahwa langkah pembinaan didahulukan daripada penindakan yustisial. Salah satu cara yang lebih efisien dalam Permendagri No. 54 Tahun 2011 adalah pembinaan kelompok yang dilakukan dengan cara mengundang/mengumpulkan kepada masyarakat dan badan hukum yang melanggar peraturan daerah untuk diberikan pengarahan dan pembinaan, arti pentingnya kesadaran dan kepatuhan terhadap Perda.

Namun kelemahan dalam menjalankan pembinaan masyarakat terkait Perda No. 10 Tahun 2013 adalah tidak adanya database yang komprehensif tentang titik/wilayah asal pelanggar maupun kelompok masyarakat yang berpotensi menjadi pelanggar ketertiban tertentu. Data penindakan yang dilakukan Satpol PP selama Maret-Oktober 2015 menunjukkan bahwa asal wilayah pelanggar sebagian besar dari luar Kabupaten Sidoarjo dan Kecamatan Sidoarjo. Namun data ini tentunya dapat dipertajam lagi untuk memperoleh gambaran lebih spesifik terkait kelompok masyarakat atau wilayah asal dari pelanggar Perda yang memiliki potensi melakukan pelanggaran berkali-kali.

c. Substansi Perda No. 10 Tahun 2013 terlalu luas bagi aparat penegak hukum 
Substansi Perda No. 10 Tahun 2013 bagi aparat penegak Perda (Satpol PP) justru terlalu luas ruang lingkupnya sehingga sulit untuk dimaksimalkan efektivitas penyelenggaraanya. Hal ini juga dikaitkan dengan masih adanya ketentuan pelanggaran dalam Perda tersebut yang dapat dioptimalkan dengan Perda lainnya.

Misalnya, permasalahan tertib kesehatan (Pasal 14 sampai dengan Pasal 18) dapat dioptimalkan dengan Perda yang khusus mengatur pengawasan dan pengendalian minuman beralkohol yang disinkronkan dengan substansi Perpres No. 74 Tahun 2013. Selain itu permasalahan tertib bangunan seharusnya diatur dalam Perda yang khusus mengatur bangunan gedung, dalam konteks Kabupaten Sidoarjo adalah Peraturan Daerah Nomor 7 Tahun 2013 tentang Bangunan Gedung.

Jika ruang lingkup ketertiban tertentu dalam Perda No. 10 Tahun 2013 dapat diatur dalam Perda lain yang lebih spesifik tentunya akan memudahkan pengawasan karena SKPD lain - selain Satpol PP memiliki pengetahuan teknis yang lebih mumpuni dalam melakukan pembinaan dan pengawasan terhadap jenis ketertiban tersebut. ${ }^{26}$ Oleh karena itu, sebelumnya perlu dipertegas ruang lingkup ketertiban dan ketentraman yang secara umum dapat diatur dalam sebuah Perda dan ruang lingkup ketertiban dan ketentraman yang secara khusus diatur dalam Perda lain yang bersifat teknis.

\section{d. Budaya hukum berbenturan dengan substansi hukum}

Law is always society as well as society is always in the law. Namun dalam praktik legislasi tidak selamanya demikian. Menurut Eugen Ehrlich (Fundamental Principles of The Sociology of Law, 1975) dalam kenyataannya law is not - or not always - society. Kondisi ini terjadi apabila hukum negara yang dikenali juga sebagai hukum perundang-undangan nasional yang positif itu tidak berawal dari hukum rakyat yang hidup dalam masyarakat. Alih-alih, hukum negara itu, walau dinyatakan resmi sebagai hukum nasional, akan tetap saja terpandang sebagai hukum yang asing bagi masyarakat.

Berdasarkan pemaparan data sebelumnya telah ditunjukkan bahwa Perda No. 10 Tahun 2013 bagi beberapa pihak dianggap membebani. Perda No. 10 Tahun 2013 dianggap membebani karena materi muatan dalam Perda tersebut melarang perilaku yang menjadi keseharian masyarakat. Sebagai contoh adalah larangan untuk membiarkan hewan peliharaan berkeliaran di jalan. Bagi masyarakat pedesaan, perilaku tersebut merupakan keseharian dan dianggap sebagai kewajaran. Namun perilaku tersebut ternyata menjadi larangan dalam Perda No. 10 Tahun 2013 yang tentunya ditujukan untuk ketertiban maupun keamanan pengguna jalan. Oleh karena itu bagi masyarakat justru menjadi beban

26 Wawancara dengan M. Sulton Hasan, Kasi Penyidikan dan Penyelidikan Satpol PP Kabupaten Sidoarjo, tanggal 26 Oktober 2015. 
karena bertolakbelakang dengan kenyataan perilaku sehari-hari yang dianggap wajar.

Selain itu konsep ruang publik tertib dan tentram yang dipahami masyarakat tampaknya berbeda dengan konsep ruang publik tertib dan tentram yang diatur dalam Perda No. 10 Tahun 2013. Beberapa pihak tentunya masih belum bisa menyadari dan memahami, misalnya, latar belakang adanya kewajiban membuat sumur resapan air hujan pada setiap bangunan yang akan dibangun sebagai bagian dari ketertiban dan ketentraman.

Beberapa ketentuan juga membutuhkan dorongan agar warga memiliki kesadaran dalam mematuhinya. Kesadaran untuk patuh tersebut dapat diarahkan dengan menyediakan sarana yang dibutuhkan agar ketentuan tersebut menjadi wajib dipatuhi. Misalnya, terkait tertib jalan, jalur hijau, trotoar, taman dan fasilitas umum lainnya dengan menyediakan tempat sampah yang cukup di berbagai titik keramaian warga. Contoh lainnya adalah ketentuan larangan memarkir kendaraan di atas trotoar harus diimbangi dengan penyediaan lahan parkir yang cukup dan mudah diakses oleh pengguna kendaraan bermotor.

\section{Kesimpulan dan Saran}

Data dan pemaparan di sub-bab sebelumnya menunjukkan bahwa penyelenggaraan Perda No. 10 Tahun 2013 tidak berjalan mulus. Terdapat hambatan atau kendala yang ditemukan dalam penyelenggaraanya. Hambatan atau kendala tersebut berasal dari internal maupun eksternal pemerintahan. Sedikitnya terdapat 5 (lima) hambatan atau kendala yang mempengaruhi keberhasilan penyelenggaraan Perda No. 10 Tahun 2013. Lima hambatan atau kendala tersebut antara lain mencakup keterbatasan sumber daya manusia dalam penegakan hukum, ancaman sanksi pidana yang belum memberikan efek jera, lemahnya sosialisasi yang membentuk pemahaman masyarakat terhadap Perda No. 10 Tahun 2013, substansi Perda No. 10 Tahun 2003 yang terlalu luas bagi aparat penegak hukum, dan budaya hukum yang berbenturan dengan substansi hukum dalam Perda No. 10 Tahun 2013.

Oleh karena itu dapat direkomendasikan beberapa saran untuk meningkatkan efektivitas penyelenggaraan Perda No. 10 Tahun 2013. Beberapa saran tersebut antara lain:

1. Penyediaan database yang komprehensif terkait wilayah rawan pelanggaran, profil pelanggar dan motif-motif pelanggaran. Database tersebut akan dapat dimanfaatkan oleh Pemerintah Daerah untuk memetakan profil kelompok-kelompok masyarakat yang sering menjadi pelanggar maupun wilayah pelanggaran yang sering menjadi tempat pelanggaran.

2. Meningkatkan fungsi sosialisasi dan pembinaan sebagai pencegahan selain penindakan yustisial. Fungsi pembinaan 
tersebut difokuskan terhadap kelompok-kelompok masyarakat yang pada umumnya melakukan pelanggaran. Oleh karena itu terlebih dahulu dibutuhkan database profil pelanggar untuk menentukan kelompok masyarakat yang menjadi sasaran pembinaan.

3. Revitalisasi peranan pemerintah desa dalam meningkatkan kesadaran hukum terhadap Perda No. 10 Tahun 2013. Pemerintah desa dapat menindaklanjuti Perda No. 10 Tahun 2013 dengan membentuk Peraturan Desa. Peraturan Desa tersebut mengatur ketertiban dan ketentraman sehingga peran pemerintah desa menjadi lebih vital dalam menjaga ketertiban dan ketentraman di Kabupaten Sidoarjo. Pembentukan Peraturan Desa tersebut merupakan penjabaran atas berbagai kewenangan yang dimiliki Desa mengacu pada ketentuan Perda No. 10 Tahun 2013.

4. Penyediaan sarana yang menunjang kepatuhan warga terhadap Perda No. 10 Tahun 2013. Penyediaan sarana tersebut juga diimbangi dengan penyediaan media-media sosialisasi laranganlarangan dalam Perda No. 10 Tahun 2013. Media sosialisasi tersebut secara masif ditempatkan pada ruang publik yang sering menjadi wilayah pelanggaran Perda. Melalui media sosialisasi tersebut masyarakat secara rutin diberikan pengetahuan tentang apa yang seharusnya dilakukan dan tidak seharusnya dilakukan. Media sosialisasi tersebut kemudian dilengkapi dengan sarana untuk melaksanakan apa yang seharusnya dilakukan atau tidak seharusnya dilakukan.

Terkait dengan ruang lingkup Perda No. 10 Tahun 2013 yang luas dan adanya ketentuan yang tidak sinkron dengan peraturan perundangundangan yang lebih tinggi, maka untuk tahap jangka menengah dibutuhkan perubahan terhadap Perda No. 10 Tahun 2013. Perubahan tersebut dengan sebelumnya perlu mengkaji ruang lingkup ketertiban dan ketentraman yang secara umum dapat diatur dalam sebuah Perda dan ruang lingkup ketertiban dan ketentraman yang secara khusus diatur dalam Perda lain yang bersifat teknis. Sinkronisasi dengan peraturan perundang-undangan yang lebih tinggi juga perlu dilakukan agar Perda yang mengatur ketertiban dan ketentraman tidak bertentangan dengan peraturan perundang-undangan yang lebih tinggi. 


\section{Daftar Pustaka}

\section{Buku}

Fedrian, Dinal, et.al. Dialektika Pembaruan Hukum Indonesia. Jakarta: Sekretariat Jenderal Komisi Yudisial RI, 2012.

J.E.,Jonkers. Buku Pedoman Hukum Pidana Hindia Belanda. Jakarta: PT. Bina Aksara, 1987.

Rahardjo, Satjipto. Hukum dalam Jagat Ketertiban. Jakarta: Penerbit UKI Press, 2006.

Sholehuddin. Sistem Sanksi dalam Hukum Pidana: lde Dasar Double Track Sistem \& Implementasinya. Jakarta: PT Raja Grafindo Persada, 2003.

Soerjono Soekanto. Beberapa Cara dan Mekanisme dalam Penyuluhan Hukum. Jakarta: Pradnya Paramita, 1986.

Tim Penelitian BPHN. Penelitian Hukum tentang Dampak Penyuluhan Hukum terhadap Tingkat Kesadaran Hukum Masyarakat. Jakarta: BPHN, 2011.

Wignjosoebroto, Soetandyo. Hukum: Konsep dan Metode. Malang: Setara Press, 2013.

\section{Artikel}

Oppusunggu, Yu Un. "Pertemuan Ilmu Hukum dan Sosiologi dalam Penerapan Lembaga Ketertiban Umum", Law, Soeciety \& Development, Vol. II, No. 3, (2008).

Crutchfield, Robert D. dan Charis E. Kubrin. "Urban Crime - Are Crime Rates Higher In Urban Areas?, Explaining Urban Crime, Explaining Variation In Urban Crime”. <http://law.jrank.org/pages/2227/Urban-Crime.html>, diakses tanggal 10 Desember 2015.

Dahniel, Rycko Amelza. "Pengelolaan Mobilitas Penduduk guna Mencegah Konflik Sosial dalam rangka Ketahanan Nasional." <http://polisikita.id/index.php/kriminologi/44-pengelolaanmobilitas-penduduk>, diakses tanggal 10 Desember 2015.

\section{Peraturan Perundang-undangan}

Indonesia, Undang-Undang Desa, UU No. 6 Tahun 2014, Lembaran Negara Republik Indonesia (LNRI) Tahun 2014 Nomor 7, dan Tambahan Lembaran Negara (TLN) Nomor 5495. 
Undang-Undang Pemerintahan Daerah, UU No.23 Tahun 2014, Lembaran Negara Republik Indonesia (LNRI) Tahun 2014 Nomor 244, dan Tambahan Lembaran Negara (TLN) Nomor 5587.

, Peraturan Pemerintah tentang Satuan Polisi Pamong Praja, PP No. 6 Tahun 2010, Lembaran Negara Republik Indonesia (LNRI) Tahun 2010 Nomor 9, dan Tambahan Lembaran Negara (TLN) Nomor 5094. 